\title{
Shallow marine bioerosion at Vardø, arctic Norway
}

\author{
RICHARD G. BROMLEY AND NILS-MARTIN HANKEN
}

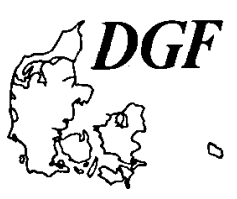

\begin{abstract}
Bromley, R. G. \& Hanken, N.-M.: Shallow marine bioerosion at Vardø, arctic Norway. Bull. geol. Soc. Denmark, vol. 29, pp. 103-109. Copenhagen, January 19th, 1981. https://doi.org/10.37570/bgsd-1980-29-05

Bioerosion was studied at Vardø, northern Norway. Only those substrates that were composed of carbonate (skeletal material) were found to be attacked by organisms. The bioeroding community is dominated by boring algae, which have entered almost every grain. Most surfaces have been rasped by patellid gastropods and some by regular echinoids. Boring sponges, annelids and phoronids are less common, whereas bivalve and, possibly, sipunculid borings were not recorded. The bioeroding community is thus impoverished, in comparison with warm-water communities, and this impoverishment is probably due to the low water temperature.
\end{abstract}

R. G. Bromley, Institut for Historisk Geologi og Palaontologi, Øster Voldgade 10, DK-1350 København K, Denmark; N.-M. Hanken, Institutt for Biologi og Geologi, Postboks 790, N-9001 Tromsø, Norway. February 15th, 1980.

Processes of breakdown of hard substrates by boring and gnawing organisms, collectively known as bioerosion, have received increased attention from biologists and palaeontologists in recent years. The work of these substrate-degrading organisms is eminently preservable in the fossil record as a detailed bioerosion sculpture on the surfaces of shells and rock, and variations in the morphology of the sculpture reflect variations in the constitution and behaviour of the bioeroding community. Consequently, a more intimate knowledge of such communities and their bioerosional work will improve our understanding of the processes and refine our use of the sculptures as tools in palaeoenvironmental reconstruction.

Several studies have been made in recent years of bioerosion in warm waters (e.g., MacGeachy \& Stearn 1976, Bromley 1978, Fischer in press), rather fewer in temperate waters (e.g., Farrow \& Clokie 1979) and none in Arctic or Antarctic waters. We need many more, detailed studies of bioerosion communities and the results of their work, in many contrasting environments, if we are to gain an understanding of the environmental influence on the morphology of the fossilizable sculpture. We therefore took advantage of an opportunity to sample a sea floor on the northeastern coast of Norway, about $400 \mathrm{~km}$ north of the Arctic Circle.

\section{Setting and material}

This study of skeletal breakdown has been limited to the narrow strait of Bussesundet, between mainland Norway and the island Vardø (fig. 1). Zoogeographically the area may be classified as low-arctic (Feyling-Hanssen 1955). The temperature range in the coastal waters varies from about 3 to $9^{\circ} \mathrm{C}$ (March and August means) and the salinity is fairly constant at $34 \%$ (Sætre 1973).

The tidal range in Bussesundet varies around 2.3-3 m, and this brings about considerable tidal currents. Water flow thus varies between a maximum of about $1.5 \mathrm{~m} / \mathrm{sec}$ and near stillstand (Bjørdal \& Sætre 1975). This current regime is reflected in the distribution and type of bottom sediment (fig. 1).

Along the coasts, Precambrian sandstone and shale is directly exposed at the sea floor (Jössang 1971). In 5-15 m water depth this is covered by boulders and stony gravel chiefly consisting of locally derived material. These sediments form a zone parallel to the coast and covering a slight ridge at the centre of the sound. From $0-10 \mathrm{~m}$ depth, these substrates are more or less covered by non-calcareous algae, chiefly Laminaria sp. Encrusting bryozoans, serpulids, barnacles and lithothamnioid algae dominate below $10 \mathrm{~m}$.

The deeper areas (about 15-26 m) are covered 


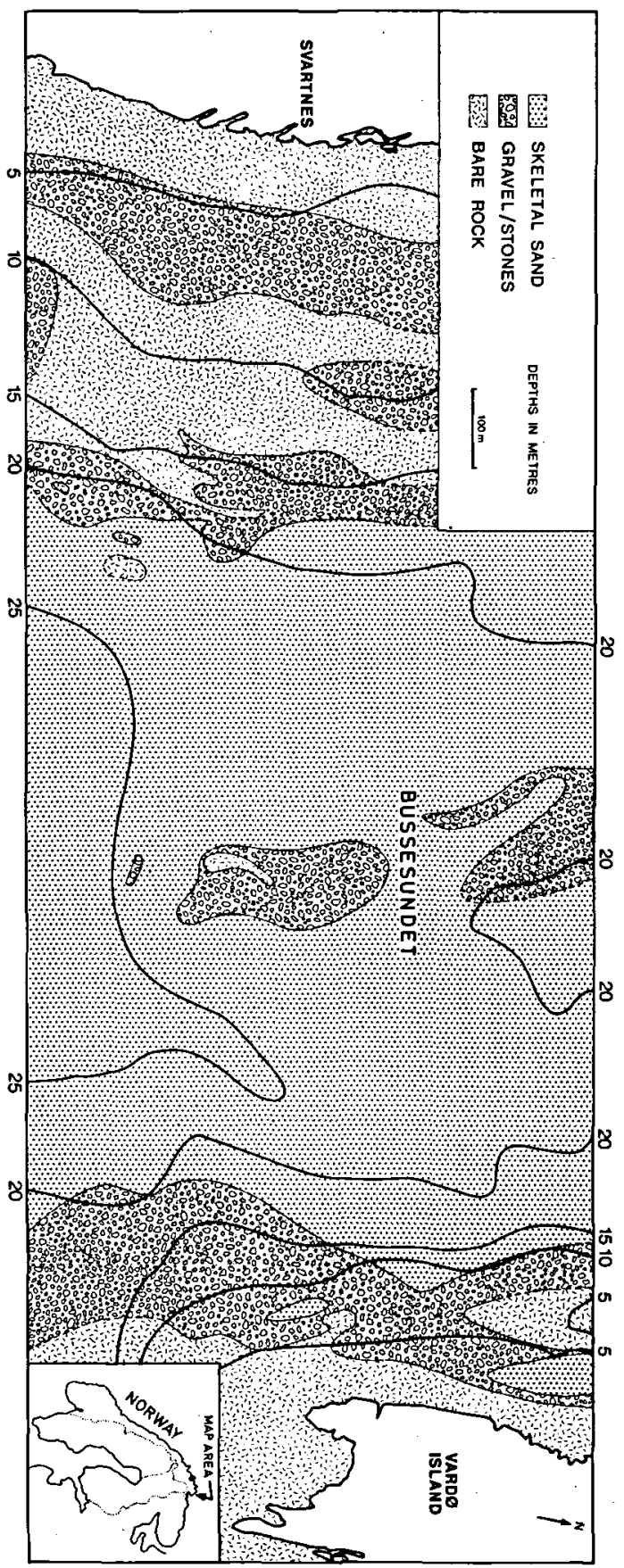

Fig. 1. Distribution of bottom types in Bussesundet. The mapping work was carried out by N.-M. H., Atle Mørk and $\mathrm{Pål}$ Svensson, using diving equipment. with coarse, skeletal sands to fine gravel. These sediments have a thickness of 3-3.5 $\mathrm{m}$ and lie directly on till (Korpberget 1976). The sediments are poorly sorted; grain size lies chiefly between 0.25 and $5 \mathrm{~mm}$, but grades continuously up to complete shells several centimetres across. The sediment includes rounded clasts derived from the country rock, and quartz sand, but these components comprise less than $5 \%$ of the sediment. The remainder consists of more or less fragmented bivalve, barnacle, echinoid and serpulid skeletons, in that order of abundance, and these appear to be entirely of local origin.

Samples of the gravel and skeletal sand were collected, together with a number of complete valves of Modiolus modiolus, one valve of Chlamys islandica and a large fragment of Arctica islandica. A lithothamnioid rhodolite was also collected, apparently having grown on a nucleus of $A$. islandica shell. This material is housed at the Palaeontological Museum, University of Oslo, Norway.

\section{Bioerosion}

A thin section of the skeletal sand reveals that nearly all carbonate grains are bored by algae. Those that are not are all of echinoderm origin. In many grains the infection is so intense that the original structure and nature of the grain are unrecognizable (fig. 2).

By reflected light under a binocular microscope, the grains are seen to form a continuous series, from those having an unabraded, fresh surface retaining the original colour and form of the skeleton, passing through all intermediate stages to rounded, well abraded grains. The latter have a dull surface of pale blue-green colour, some pink, indicating boring by Cyanophyceae and Rhodophyceae. The series apparently reflects the period of time spent by individual grains at the depositional interface; i.e., from 'new' grains to 'old'.

Many of the larger grains also contain fragments of borings that, to judge from their morphology, were produced by phoronids and clionid sponges. The surfaces of few grains, however, bear recognizable bioerosion sculpture. It seems that their attrition was dominantly mechanical, having occurred during transport in the tidal 

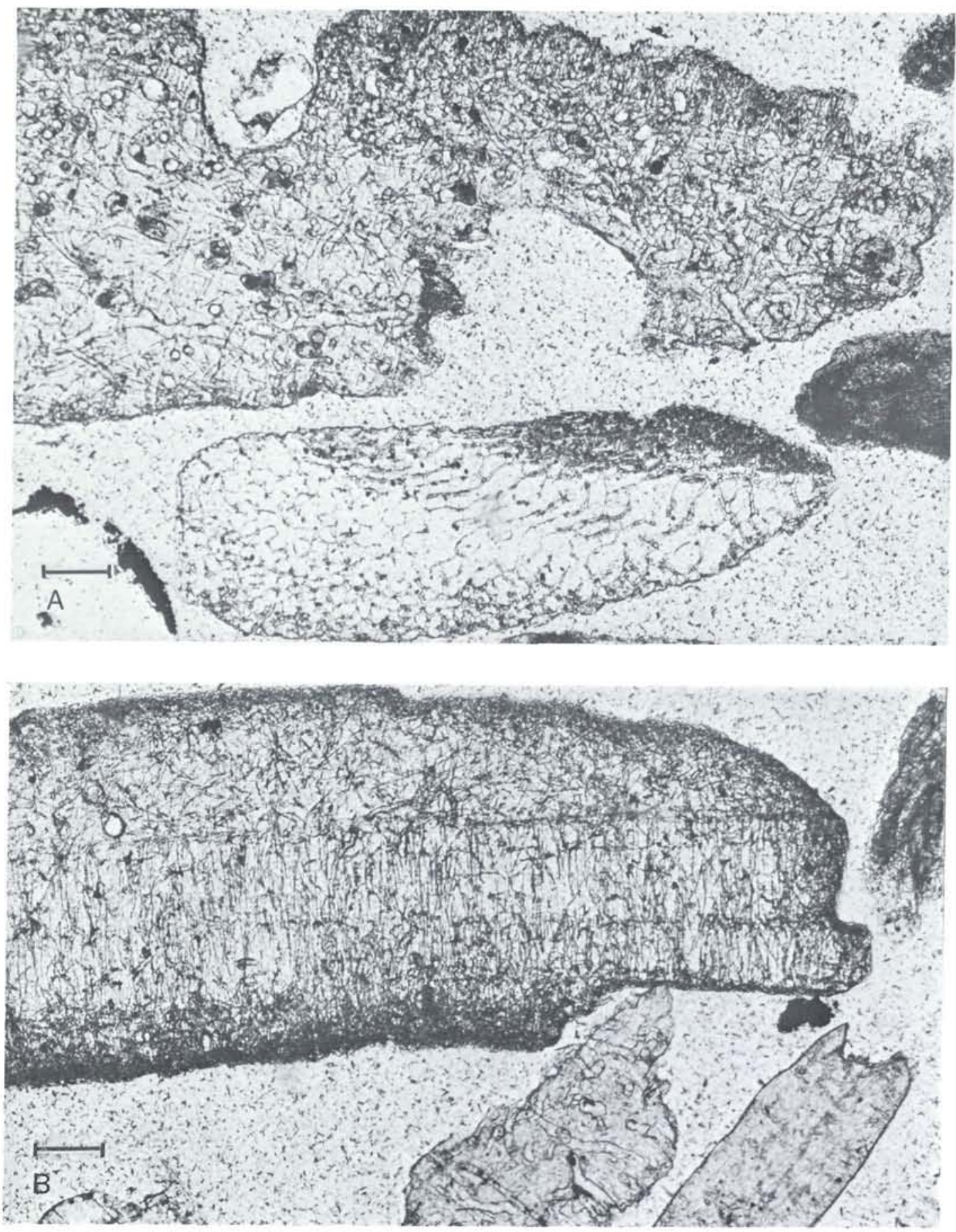

Fig. 2. Thin sections of grains from the skeletal sand, $\times 100$, scale bars $100 \mu \mathrm{m}$. A: the upper grain is of molluscan origin, the lower echinoderm. The echinoderm fragment is unbored (the tubule network is stereome) and its smooth surface reflects the physical process of rounding. The upper grain is riddled with microphytic borings, the larger (up to $20 \mu \mathrm{m}$ wide) probably of green and/or red algae, the very fine ones of blue-green algae. The irregular outline of the grain reflects the role played by bioerosion in its breakdown. B: mollusk shell fragments showing varying degrees of microphyte attack. The grains at top and lower right contain almost exclusively fine borings attributable to blue-green algae. The topmost grain shows advanced attack at the margins. The irregular grain at bottom centre contains wider borings $(10-17 \mu \mathrm{m})$ probably produced by green algae. 


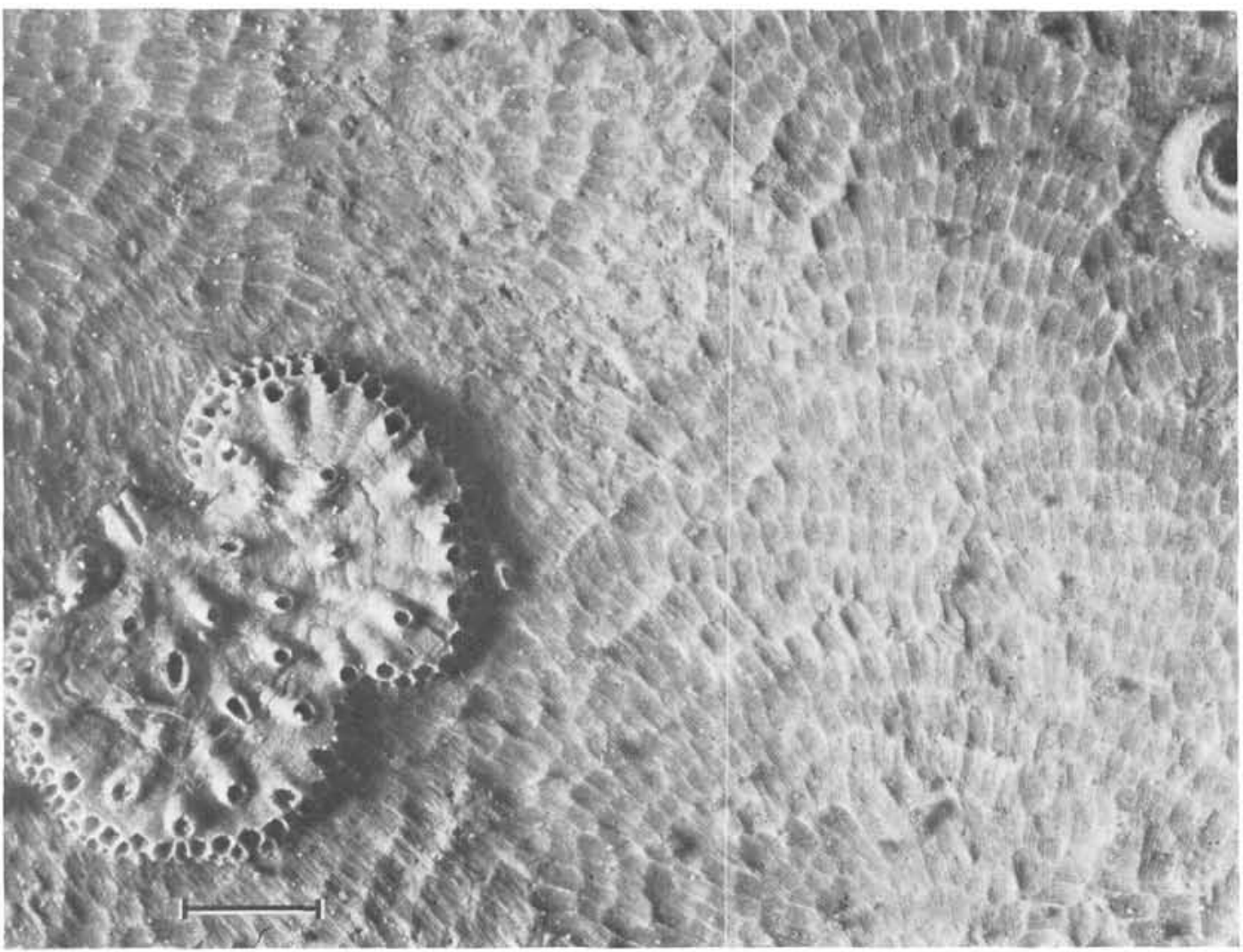

Fig. 3. Radula erosion attributable to the work of Acmaea testudinalis, on an algal-bored, inner surface of the valve of Chlamys islandica. $\times 16$, scale bar $1 \mathrm{~mm}$.

current, but assisted by weakening through the boring activity of algae.

The larger shells over about $7 \mathrm{~cm}$ in diameter do not seem yet to have been greatly transported. However, they have been mechanically abraded on the convex side, and bioerosion sculpture is only patchily preserved on that surface. On the protected, concave side, bioerosion sculpture is perfectly preserved.

\section{Gastropod radula traces}

The commonest form of bioerosion on the larger shells is a distinctive form of radula erosion (fig. 3). Throughout the material it is all of one type, characteristic of the docoglossid radula (Voigt 1977). In two cases the causative organism, $A c$ maea testudinalis, is preserved in dried condition, in situ on its trace (fig. 4). The two animals are 'homed', i.e., located at the centre of their re- spective grazing areas, all radula traces in the nearby substrate radiating out from the centre. The boundaries of a grazing territory with those of neighbouring snails or with temporarily ungrazed areas are conspicuous; the first case is marked by a change in direction of the grazing orientation, whereas the unoccupied areas have in addition a thin, dark, epilithic algal growth on the surface. Thus the larger animal, having a shell length of $10 \mathrm{~mm}$, had a grazing territory on a $M$. modiolus shell covering about $800 \mathrm{~mm}^{2}$ and the smaller, $5 \mathrm{~mm}$ long, had a territory of about 600 $\mathrm{mm}^{2}$ on the $C$. islandica shell. The depth of each rasp of the radula is considerable, reaching in places up to $100 \mu \mathrm{m}$.

The entire concave side and most of the convex side of the $C$. islandica shell is covered with this characteristic grazing pattern. A detailed account of this type of radula grazing has been given by Farrow \& Clokie (1979). 


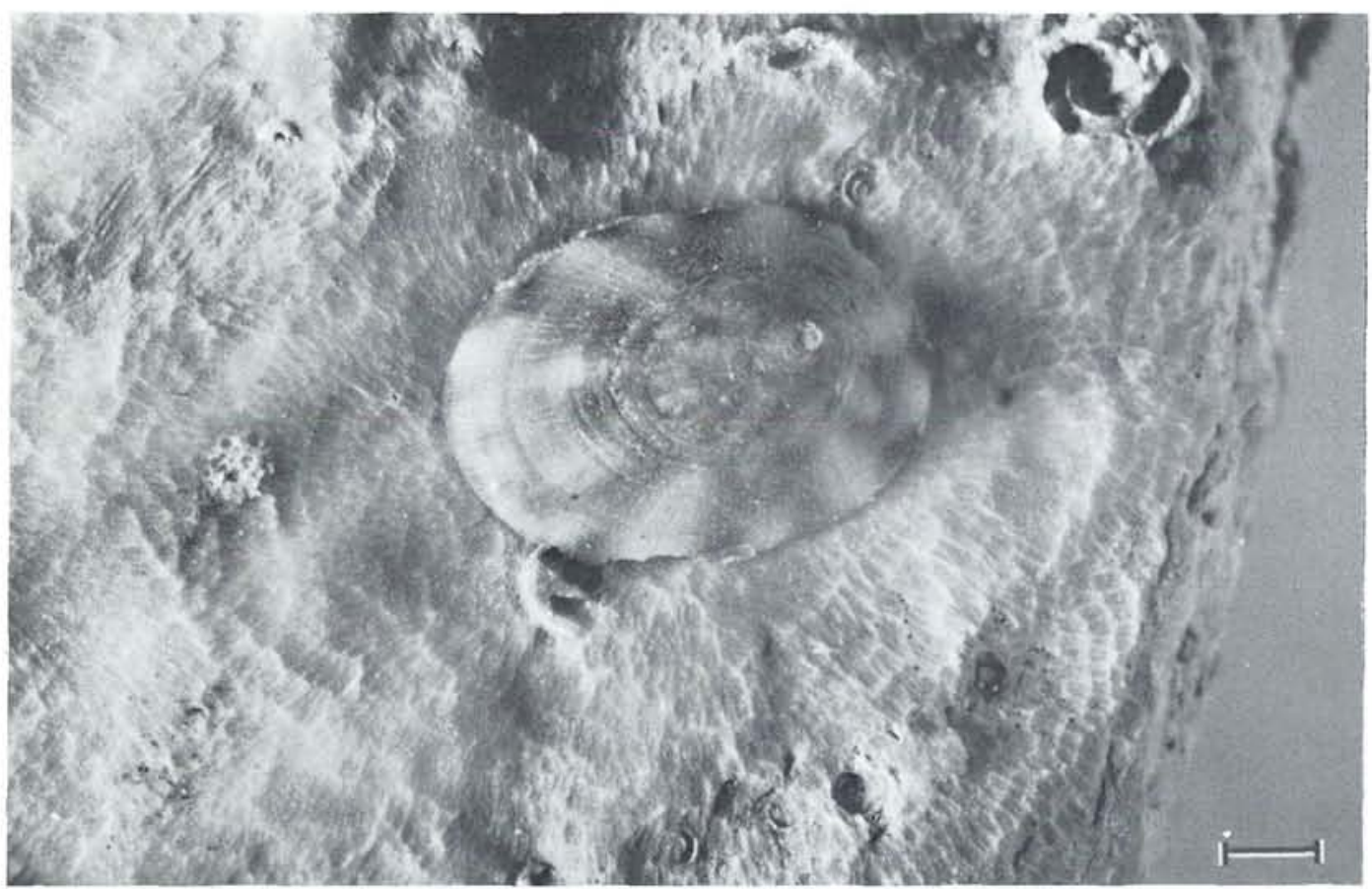

Fig. 4. Juvenile Acmaea testudinalis in situ on the outer surface of the Chlamys islandica valve; note the radiating orientation of the bioerosion sculpture around the 'homed' gastropod. $\times 10$, scale bar $1 \mathrm{~mm}$.

Echinoid dental traces

The stellate bite traces of grazing regular echinoids in hard, calcareous substrates are characteristic (Bromley 1975). In the present material they occur on the concave side of some of the M. modiolus valves and the Arctica islandica fragment (fig. 5). The sand contains abundant plates and spines of the genus Strongylocentrotus, and these were identified by Margit Jensen (personal communication 1978) as belonging to both of the Arctic species, $S$. droebachiensis and $S$. palidus. It is not possible to distinguish between the work of these two species. Some small stellate traces indicate the activity of juvenile individuals. The shell surfaces have only been grazed over lightly and do not seem to indicate activity within restricted territories.

\section{Sponge boring}

In addition to the fragments of borings in small grains, a single $M$. modiolus has been bored by a sponge, in part at least after the death of the mollusc. Although most of the boring is now empty, one place contains sponge tissue that has yielded spicules that identify the sponge as Cliona vastifica. A radiograph shows the morphology of the boring to be consistent with that typical for the species (fig. 6) (cf. Evans 1969, fig. 1; Bromley 1970. pl. 3).

An echinoid has grazed over the concave surface of this substrate and has paid some, but not exclusive, attention to the papillae of the sponge. The shell surface is relatively fresh, however, containing little endolithic algae, and the echinoid may have attacked the sponge papillae in passing, in the absence of sufficient algae.

\section{Phoronid boring}

Radiography of the $M$. modiolus shells revealed in one valve the minute boring of a phoronid pseudocolony (fig. 7). It is likely that this is the work of Phoronis ovalis, a boring form that is common in the nearby North Sea (cf. Brattström 1943; Voigt 1972; 1975).

\section{Polychaete borings}

A single U-boring resembling the work of a spionid polychaete, perhaps Polydora ciliata, is 


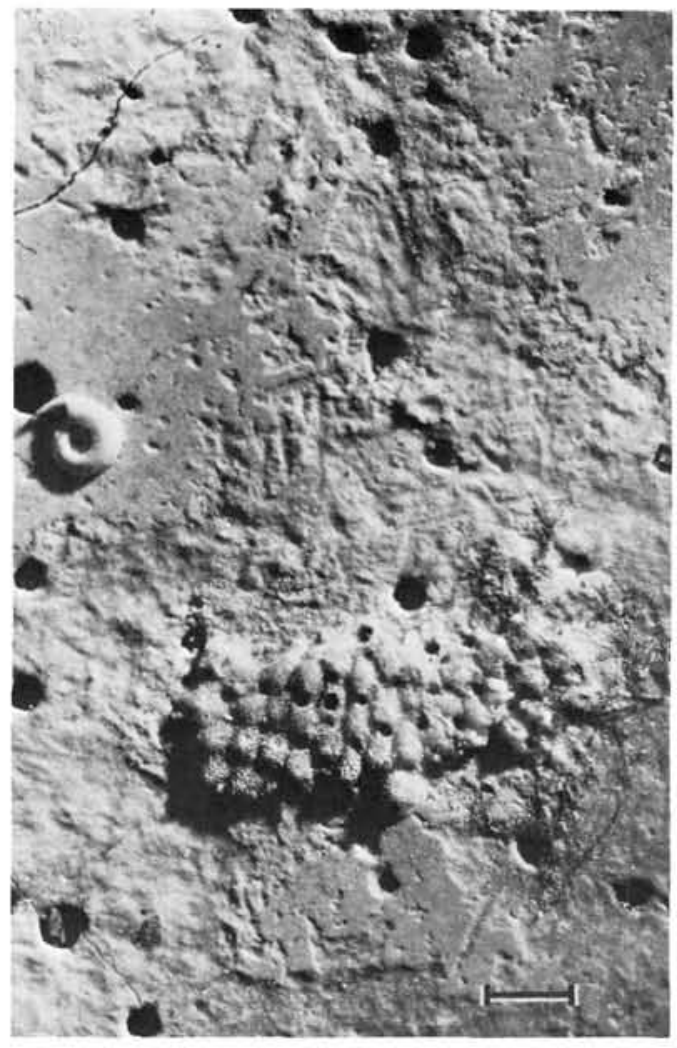

Fig. 5. Echinoid dental erosion on the concave side of a $M$. modiolus shell. Around the Spirorbis tube and at top right and bottom, parts of the original shell surface survive. Elsewhere this has been removed together with part of the bryozoan colony by a browsing echinoid. The round holes are papillar openings to the Cliona vastifica boring (fig. 6). Only one of these openings, at top left, has obviously received special attention from the echinoid. $\times 9$, scale bar $1 \mathrm{~mm}$.

present in a $M$. modiolus shell. The shell fragment within the rhodolite has been intensely bored by worms, probably by sabellid polychaetes. The substrate is riddled with subcylindrical passages around $1 \mathrm{~mm}$ in width, which have been partly filled with sand by secondary, nestling inhabitants. The possibility of other polychaete or even sipunculid borers being responsible for these cavities cannot be excluded, the morphology being very simple.

\section{Bioerosion sculpture and geological significance}

Every available substrate has been bored by algae. The bioerosion sculpture is dominated by

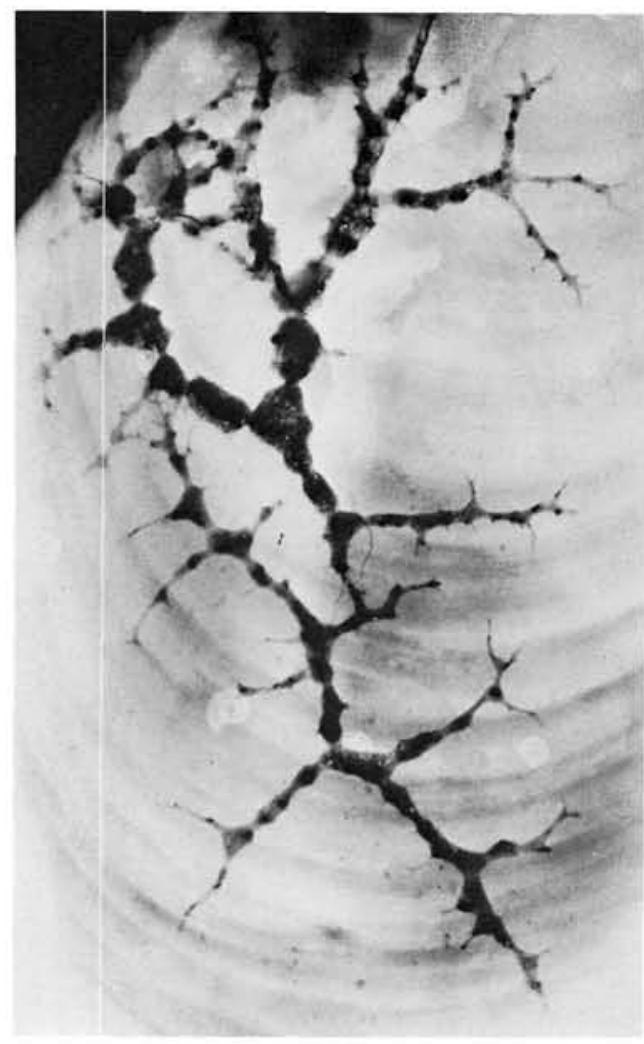

Fig. 6. Radiograph (negative print) of the boring of Cliona vastifica in a valve of $M$. modiolus. $\times 2$.

gastropod grazing traces, next to which in importance are echinoid grazing traces. There would seem to be a direct connection between the abundance of endolithic algae and grazing traces. Other types of bioerosion are of secondary importance; sponge and phoronid borings are not common and worm borings are rare. Bivalve and possibly sipunculid borings are not represented.

In a fossil occurrence, bioerosion of this type should be readily identifiable as one typical of the euphotic zone. It is not clear whether any feature of the bioerosion assemblage would give a clue as to the low water temperature. Perhaps the unusually low incidence of sponge, phoronid and worm borings and the absence of bivalves is related to this; five out of seven $M$. modiolus valves contain no macroborings.

At present, bioerosion is selectively destroying the carbonate fraction of the sediment, which is replenished through proximity to its source area. There is no indication that sea floor dissolution is 


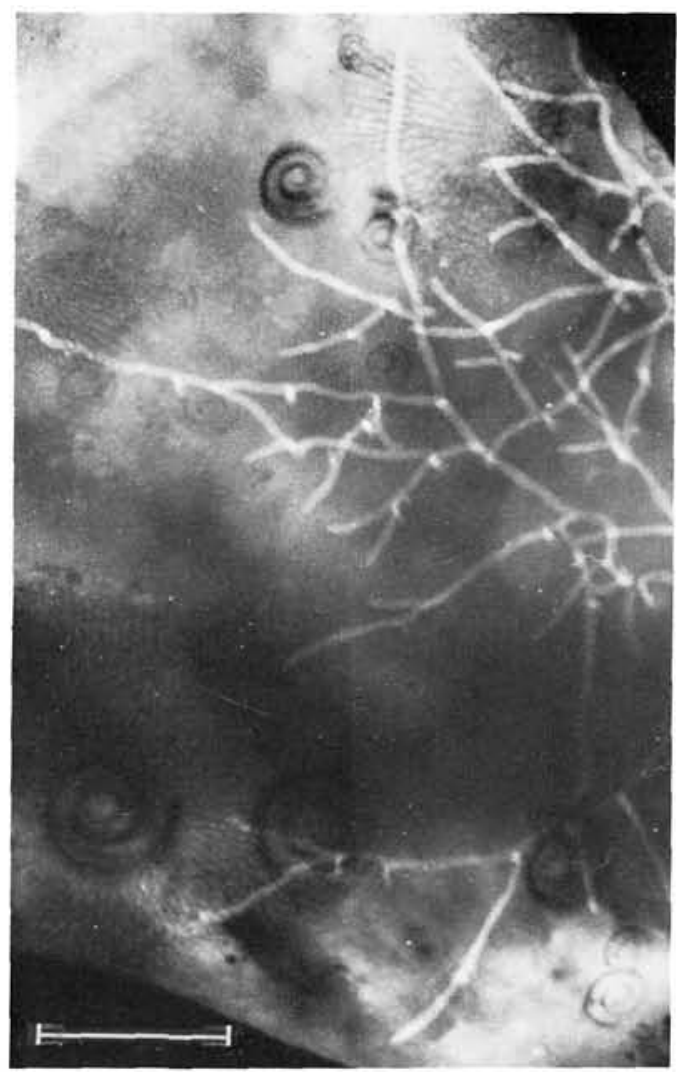

Fig. 7. Radiograph (positive print) of the phoronid boring in a M. modiolus shell. $\times 4$, scale bar $5 \mathrm{~mm}$.

taking place in Bussesundet such as Alexandersson (1978) has described for the Skagerrak. However, we have not extended our study to include an SEM examination of the material.

The carbonate fraction is being broken down by a combination of biological and physical means, and most of the carbonate material that the tidal current delivers to nearby depositional areas will be of mud to fine sand fractions.

\section{Dansk sammendrag}

Bioerosion (nedbrydning af hårde substrater som et resultat af organismers livsprocesser) er blevet studeret $\mathrm{i}$ et lav-arktisk område. Kun substrater bestående af kalciumkarbonat skeletmateriale var angrebet. Blandt de bioeroderende organismer var borende alger de dominerende; de havde angrebet alle karbonatkorn bortset fra nogle echinodermkorn. De fleste overflader bar raspemæerker fra patellide snegle og i nogle tilfælde fra regulære søpindsvin. Borende svampe, annelider og phoronider var mindre hyppige, mens borende muslinger ikke blev fundet. Det bioeroderende selskab er artsfattigt sammenlignet med varmere haves; denne fattigdom skyldes rimeligvis den lave havtemperatur.

\section{References}

Alexandersson, E. T. 1978: Destructive diagenesis of carbonate sediments in the eastern Skagerrak, North Sea. Geology 6: 324-327.

Bjørdal, S. \& Sætre, H. J. 1975: Bølge- og strømforhold i Bussesundet. Unpubl. Rpt. Vassdrags- og Havnelab., Norges tekn. Høgsk., Trondheim, nr. 601349, 28 pp.

Brattström, H. 1943: Untersuchungen aus dem Öresund: 28. Phoronis ovalis Wright, eine für die Skandinavische Fauna neue Phoronide aus dem Öresund. Lunds Univ. Arsskr. N. F., (2) 39: $17 \mathrm{pp}$.

Bromley, R. G. 1970: Borings as trace fossils and Entobia cretacea Portlock, as an example. Geol. J. special Issues 3: 49-90.

Bromley, R. G. 1975: Comparative analysis of fossil and recent echinoid bioerosion. Palaeontology 18: 725-739.

Bromley, R. G. 1978: Bioerosion of Bermuda reefs. Palaeogeogr., Palaeoclimatol., Palaeoecol. 23: 169-197.

Evans, J. W. 1969: Borers in the shell of the sea scallop Placopecten magellanicus. Am. Zoologist 9; 775-782.

Farrow, G. E. \& Clokie, J. 1979: Molluscan grazing of sublittoral algal-bored shells and the production of carbonate mud in the Firth of Clyde, Scotland. Trans, roy. Soc. Edinburgh 70: 139-148.

Fischer, R. in press: Bioerosion von Basalt der Pazifikküste Costa Ricas. Neues Jb. Geol. Paläont., Abh.

Feyling-Hanssen, R. W. 1955: Stratigraphy of the marine Late-Pleistocene of Billefjorden, Vestspitsbergen. Norsk Polarinst. Skr, 107: $186 \mathrm{pp}$.

Jössang, O. 1971: Petrografiske undersøkelser ved Vardø. Nor. geol. Unders. 270: 109-128.

Korpberget, T. 1976: Bru over Bussesundet. Grunnundersokelse for alternativ nord: Smelror-Tyvholmen-Gammelslätta. Unpubl, initial Rpt. to Road Lab. Y 14, no. 6.

MacGeachy, J. K. \& Stearn, C. W. 1976: Boring by macroorganisms in the coral Montastrea annularis on Barbados reefs. Int. Revue ges. Hydrobiol. 61: 715-745.

Sætre R. 1973: Temperatur- og saltholdighetsnormaler for overuatelaget i norske kystfarvann. Fiskets Gang 59: $166-172$.

Voigt, E. 1972: Über Talpina ramosa v. Hagenow 1940. Nachrichten Akad. Wiss. Göttingen, II math.-phys. Klasse, 1972: 93-126.

Voigt, E. 1975: Tunnelbaue rezenter und fossiler Phoronidea. Paläont. Z. 49: 135-167.

Voigt, E. 1977: On grazing traces produced by the radula of fossil and Recent gastropods and chitons. Geol. J. special Issues 9: 335-346. 